\title{
Prevention of Premenstrual Exacerbation of Hereditary Coproporphyria by Gonadotropin-Releasing Hormone Analogue
}

\author{
Ikuo Yamamori, Masato Asai, Fumi TanaKa, Akiko Muramoto and Haruhiko Hasegawa
}

\begin{abstract}
A 20-year-old Japanese female needed frequent hospitalization due to premenstrual exacerbation of hereditary coproporphyria (HCP). Intranasal buserelin acetate, a gonadotropin-releasing hormone analogue, was given to suppress her menstrual cycles. Her porphyric symptoms subsided dramatically as she became amenorrhoeic. Urinary excretion of porphyrin derivatives fell significantly. She has been free from recurrent attacks, but suffers a minor porphyric attack once in 5 years. However, borderline osteopenia secondary to hypoestrogenism has been noted. Although these analogues are potent in suppressing estrogen-induced porphyric symptoms, due precautions should be taken to avoid bone demineralization in the long-term use. (Internal Medicine 38: 365-368, 1999)
\end{abstract}

Key words: buserelin, luteinizing-hormone releasing hormone analogue, porphyria

\section{Introduction}

Hereditary coproporphyria (HCP) is an inherited metabolic disorder caused by a reduced bioactivity of the key enzyme coproporphyrinogen oxidase, the sixth enzyme in the heme biosynthetic pathway (1). Premenstrual exacerbation is a clinical burden in patients with $\mathrm{HCP}$ as well as in those with acute intermittent porphyria (AIP) $(1,2)$. Endocrine manipulation with oral contraceptives (3), progestins or androgens (4) has been employed in some cases. Intravenous use of heme derivatives is also useful to prevent cyclical attacks in acute porphyrias $(5,6)$. Anderson and colleagues introduced agonistic analogues of gonadotropin-releasing hormone $(\mathrm{GnRH})$ to prevent such attacks in 1984 (2). Some reports have described the usefulness of these products (7-13). However, the clinical experience has been limited exclusively to patients with AIP, and in only one patient with variegate porphyria (10). We report a case of HCP showing a remarkable suppression of premenstrual exacerbation with treatment by buserelin (D$\mathrm{Ser}[\mathrm{TBU}]^{6}$-des-Gly- $\mathrm{NH}_{2}{ }^{10}$ ) acetate, a $\mathrm{GnRH}$ analogue. We also discuss the possible adverse events in the long-term use of these analogues.

For editorial comment, see also p 307.

\section{Case Report}

A 20-year-old Japanese woman was admitted to our hospital in December 1992, for premenstrual pain in the abdomen and the extremities. The early course of her medical history had been described previously $(14,15)$. Briefly, porphyria was recognized at age 15 years. Her urinary samples and those of her father demonstrated excess porphobilinogen (PBG), but those of her mother did not. She had been misinterpreted as suffering from AIP (14). Intraveneous hematin brought dramatic relief of her acute porphyric symptoms. She needed two more series of hematin infusion in February and March 1993, respectively. It was burdensome, expensive, and also potentially hazardous to continue hematin treatment (15). Buserelin acetate, one of the GnRH analogues was thus commenced to prevent recurrent attacks in April 1993 with the patient's informed consent. Since then, her urinary excretion of PBG, coproporphyrin and $\delta$-aminolevulinic acid (ALA, data not shown) fell significantly (Fig. 1). Mild hot flushes were noted to be a climacteric symptom. GnRH provocation test (100 $\mu \mathrm{g}$ i.v.) revealed almost complete suppression of both follicle stimulating hormone (4.4 to $5.7 \mathrm{IU} / l$, peak value at 120 minutes) and lutenizing hormone (1.8 to $5.8 \mathrm{IU} / l$, peak value at 30 minutes) in August 1993. She has been amenorrhoeic for 5 years with a minor porphyric attack on one occasion. Even when she suffered from acute gastroenteritis and acute hepatitis due to cytomegalovirus infection in August 1997, and diclofenac sodium, one of the porphyria-inducing agents, was accidentally given

From the Department of Internal Medicine, the Japanese Red Cross Nagoya First Hospital, Nagoya

Received for publication July 16, 1998; Accepted for publication December 22, 1998

Reprint requests should be addressed to Dr. Ikuo Yamamori, the Department of Internal Medicine, the Japanese Red Cross Nagoya First Hospital, 3-35 Michishita-cho, Nakamura-ku, Nagoya, 453-8511 


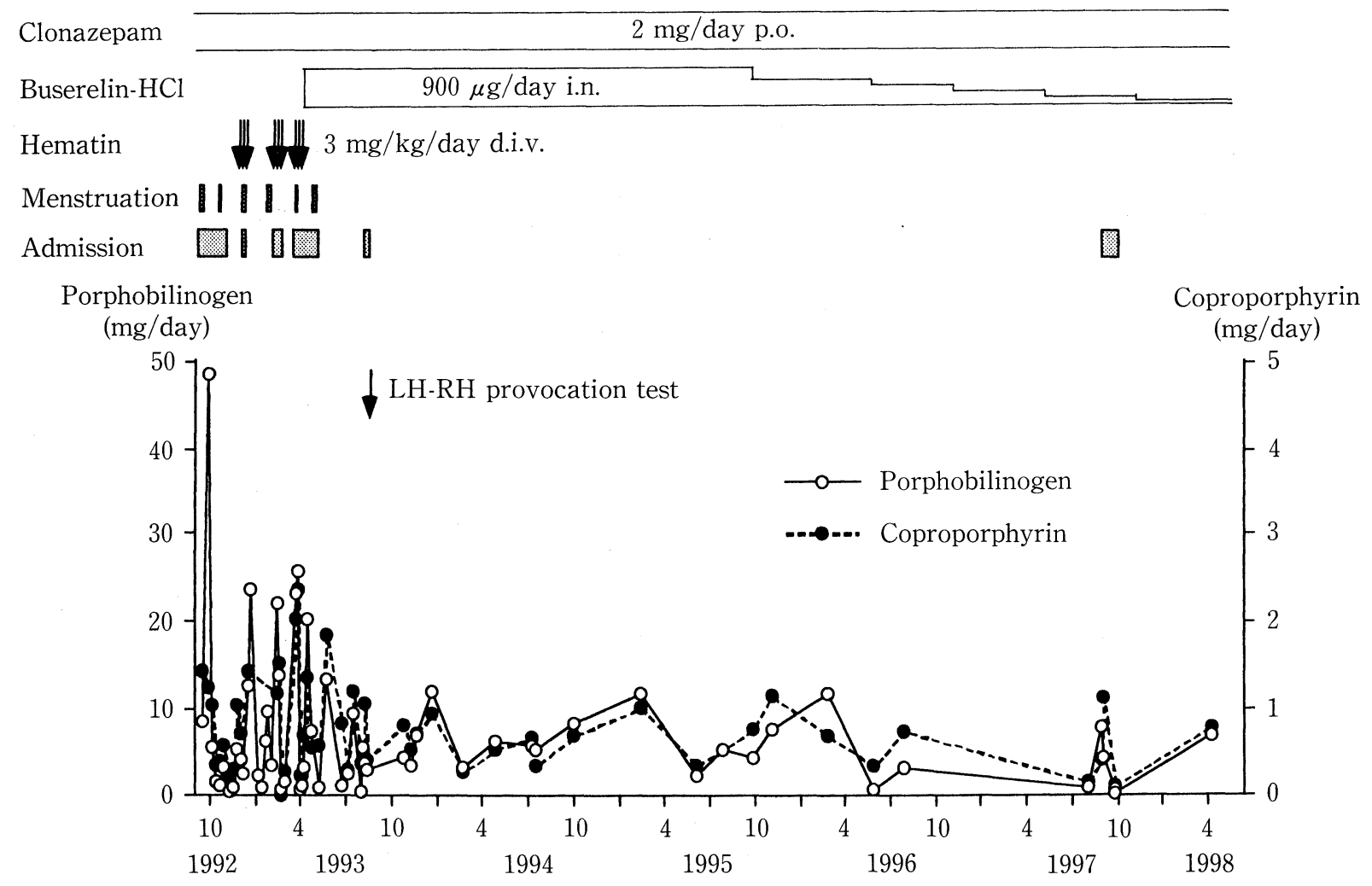

Figure 1. Clinical course and urinary excretion of porphyrin derivatives.

on this instance, she remained asymptomatic. However, the urinary excretion of porphyrin derivatives rose significantly. Urinary excretion of ALA was also mildly elevated from 3.0 to $7.6 \mathrm{mg} / \mathrm{day}$. The dosage of buserelin was carefully tapered from 900 to $150 \mu \mathrm{g}$ daily without recurring symptoms. In July 1996, the correct diagnosis of HCP was established by high performance liquid chromatography analysis of her urine and fecal sample (15). Further, a deletion mutation was demonstrated on her coproporphyrinogen oxidase gene as described elsewhere (16). In September 1997, her bone mineral density determined by X-ray bone densitometer QDR 4500 (Hologic Inc., Waltham, MA) was revealed to be $0.811 \mathrm{~g} / \mathrm{cm}^{2}$, which was $80 \%$ of the mean of age-matched females (17). Hypercholesterolemia with borderline hypertension was also noted.

\section{Discussion}

HCP is an inborn metabolic disorder resulting from a reduced bioactivity of coproporphyrinogen oxidase (1). The prevalence of the disease is lower than that of AIP. Among 612 porphyrics reported in Japan by 1993, 145 had AIP, and 23 had HCP (18). Prevalence of HCP was estimated to be two per million in Denmark (19) and 15 per million for AIP in Sweden (20). Clinical symptoms as well as treatment of HCP resemble those of AIP.

Although hematin is a potent therapeutic agent for acute porphyric attacks $(5,6)$, it brings symptomatic relief only tem- porarily (15). It is essential to carefully avoid the precipitating factors for the patients, because the disease is essentially a lifelong process. After the first report by Anderson and colleagues (2), 18 cases with acute porphyrias have been treated with GnRH analogues (Table 1). Like most cases with AIP $(2,7$ 13) or variegate porphyria (10), we observed a good response in this case. Thus, patients with HCP may be an additional indication for the treatment with the $\mathrm{GnRH}$ analogues.

$\mathrm{GnRH}$ analogues have an inhibitory effect on reproductive function through pituitary desensitization when administered repeatedly (21). Both follicle stimulating hormone and lutenizing hormone were completely suppressed in our case four months after the commencement of the agent. The implications of sex steroids in the pathogenesis of clinical porphyria remain controversial. Oral contraceptive agents have been used to prevent cyclic attacks of porphyria $(3,4)$. However, progesterone has been thought to increase heme catabolism (22), and synthetic progesterone induces clinical porphyria (23). Estrogen is generally believed to have only a weak action on porphyrin biosynthesis $(24,25)$. In this context, a lower progesterone secretion in response to pituitary suppression may lead to decreased porphyrin secretion. In fact, urinary excretion of porphyrin derivatives fell significantly after the introduction of intranasal buserelin in the present case. The clinical symptoms were also ameliorated with no further premenstrual exacerbation, except for one minor attack in five years. It should be noted that GnRH analogues did not normalize porphyrin 
GnRH Analogue for Acute Porphyria

Table 1. LH-RH Analogues for Acute Porphyrias

\begin{tabular}{|c|c|c|c|c|c|c|}
\hline Author & Year & Analogue & Route & No. of cases & Porphyria & Reference \\
\hline Anderson, KE & 1984 & {$\left[\mathrm{D}-\mathrm{His}[\mathrm{ImBzl}]^{6}\right.$, Pro$\left.^{9}-\mathrm{NEt}\right] \mathrm{GnRH}$} & s.c.* & 1 & AIP $@$ & 2 \\
\hline Anderson, KE & 1986 & {$\left[\mathrm{D}-\mathrm{His}[\mathrm{ImBzl}]^{6}, \mathrm{Pro}^{9}-\mathrm{NEt}\right] \mathrm{GnRH}$} & i.n.** & $4(3)^{\# \#}$ & AIP & 7 \\
\hline Semon, $\mathrm{C}$ & 1986 & buserelin & i.n. & 1 & AIP & 8 \\
\hline Norman, RJ & 1988 & {$\left[\mathrm{D}-\mathrm{Trp}^{6}, \mathrm{Pro}^{9}-\mathrm{NEt}\right] \mathrm{GnRH}$} & s.c.?\# & 1 & AIP & 9 \\
\hline Bargetzi, MJ & 1989 & buserelin & i.n. & 2 & AIP, VP $@ @$ & 10 \\
\hline Herrick, KEL & 1990 & buserelin & i.n. & 7 & AIP & 11 \\
\hline Anderson, KE & 1990 & {$\left[\mathrm{D}-\mathrm{His}[\mathrm{ImBzl}]^{6}\right.$, Pro $\left.^{9}-\mathrm{NEt}\right] \mathrm{GnRH}$} & s.c., i.n. & $6(2)^{\#}$ & AIP & 12 \\
\hline Bode, $\mathrm{H}$ & 1992 & buserelin & i.n. & 1 & AIP & 13 \\
\hline present report & 1999 & buserelin & i.n. & 1 & $\mathrm{HCP}^{\$}$ & - \\
\hline
\end{tabular}

*subcutaneous, **intranasal, \#originally described merely as "injected", "\# Numbers in parentheses indicate those of original cases, ${ }^{\circledR}$ acute intermittent porphyria, ${ }^{\circledR}$ variegate porphyria, ${ }^{\$}$ hereditary coproporphyria.

excretion in most cases (8-13). Clinical improvement was observed without a decrease in the porphyrin excretion in those cases. Actually, the urinary porphyrin derivatives are still higher than normal with the buserelin treatment in our case. The clinical course of porphyria is variable and spontaneous remission occurs frequently $(1,26)$. The exact mechanism by which $\mathrm{GnRH}$ analogues bring about clinical remission of porphyria remains to be elucidated.

One must be careful that the initial agonistic action of the analogues may lead to a deterioration of the porphyric symptoms. Fortunately, this condition did not occur in the present case. Hot flushes were her only symptom. Nevertheless, borderline osteopenia secondary to hypoestrogenism was observed four and a half years after the initiation of buserelin treatment. Progressive bone loss due to bone demineralization must be carefully monitored, and proper therapeutic intervention should be considered in the long-term use of these agents.

\section{References}

1) Kappas A, Sassa S, Galbraith RA, Nordmann Y. The porphyrias. in: The Metabolic and Molecular Bases of Inherited Disease. 7th Ed. Scriver CR, Beaudet AL, Sly WS, Valle D, Eds. McGraw-Hill, New York, 1995: 2103 2159.

2) Anderson KE, Spitz IM, Sassa S, Bardin CW, Kappas A. Prevention of cyclical attacks of acute intermittent porphyria with a long-acting agonist of luteinizing hormone-releasing hormone. $\mathrm{N}$ Engl J Med 311: 643-645, 1984.

3) Gro $\beta$ U, Honcamp M, Daume E, Frank M, Dusterberg B, Doss MO. Hormonal oral contraceptives, urinary porphyrin excretion and porphyrias. Horm Metab Res 27: 379-383, 1995.

4) Perlroth MG, Marver HS, Tschudy DP. Oral contraceptive agents and the management of acute intermittent porphyria. JAMA 194: 1037-1042, 1965.

5) Lamon JM, Frykholm BC, Bennet M, Tschudy DP. Prevention of acute porphyric attacks by intraveneous haematin. Lancet 2: 492-494, 1978.

6) Schoenfeld N, Mamet R, Dotan I, Sztern M, Levo Y, Aderka D. Relation between uroporphyrin excretion, acute attacks of hereditary coproporphyria and successful treatment with haem arginate. Clin Sci (Colch) 88: 365-369, 1995.

7) Anderson KE, Spitz IM, Sassa S, Bardin CW, Kappas A. Intranasal luteinizing hormone-releasing hormone agonist for prevention of cyclical attacks of acute intermittent porphyria. in: Porphyrins and Porphyrias.
Nordmann Y, Ed. John Libbey, London, 1986: 225-231.

8) Semon C, Dupond JL, Mallet H, Grandmottet-Cambefort C, Humbert P. Treatment of cyclic attacks of acute intermittent porphyria with an agonist of LH-RH by intranasal spray. Ann Endocrinol (Paris) 47: 399-402, 1986.

9) Norman RJ, Miller J, Millar RP, Joubert SM. Treatment of menstrually induced acute intermittent porphyria by a long-acting gonadotrophin-releasing hormone agonist (D Trp ${ }^{6}-$ Pro $^{9} \mathrm{~N}$ ethylamide) LHRH: case report. Br J Obstet Gynecol 95: 192-194, 1988.

10) Bargetzi MJ, Meyer UA, Birkhaeuser MH. Premenstrual exacerbations in hepatic porphyria: prevention by intermittent administration of an LHRH agonist in combination with a gestagen. JAMA 261: 864, 1989 (letter).

11) Herrick AL, McColl KEL, Wallace AM, Moore MR, Goldberg A. LHRH analogue treatment for the prevention of premenstrual attacks of acute porphyria. Q J Med 75: 355-363, 1990.

12) Anderson KE, Spitz IM, Bardin CW, Kappas A. A gonadotropin releasing hormone analogue prevents cyclical attacks of porphyria. Arch Intern Med 150: 1469-1474, 1990.

13) Bode H. GnRH-Agonisten bei akuter intermittierender Porphyrie. Dtsch Med Wochenschr 117: 1940-1941, 1992 (letter).

14) Suzuki A, Aso K, Ariyoshi C, Ishimaru M. Acute intermittent porphyria and epilepsy: safety of clonazepam. Epilepsia 33: 108-111, 1992.

15) Yamamori I, Kondo M, Hasegawa H. Treatment of hereditary coproporphyria by intraveneous hematin. Porphyrin 6: 35-40, 1997 (Abstract in English).

16) Susa S, Daimon M, Yamamori I, et al. A novel mutation of coproporphyrinogen oxidase (CPO) gene in a Japanese family. J Hum Genet 43: 182-184, 1998.

17) Orimo $H$, Sugioka $Y$, Fukunaga $H$, et al. Diagnostic criteria for primary osteoporosis (revised edition 1996). Osteoporosis Japan 4: 643-653, 1996 (in Japanese).

18) Yano Y, Kondo M, Shirataka M, Urata G. Porphyrias. Nippon Rinsho 51 Suppl: 347-362, 1993 (in Japanese).

19) With TK. Hereditary coproporphyria and variegate porphyria in Denmark. Dan Med Bull 30: 106-112, 1983.

20) Goldberg A, Rimington C. Diseases of Porphyrin Metabolism. Charles C Thomas, Springfield, IL, 1962.

21) Bergquist C, Nillius SJ, Bergh T, Skarin G, Wide L. Inhibitory effects of gonadotrophin secretion and gonadal function in men during chronic treatment with a potent stimulatory luteinizing hormone-releasing hormone analogue. Acta Endocrinol (Copenh) 91: 601-608, 1979.

22) Mercke $C$, Lundh $B$. Erythrocyte filtrability and heme catabolism during the menstrual cycle. Ann Intern Med 85: 322-324, 1976.

23) Levit EJ, Nodine JH, Perloff WH. Progesterone-induced porphyria. Am J Med 22: 831-833, 1957.

24) Anderson KE, Freddara U, Kappas A. Induction of hepatic cytochrome 


\section{YAMAMORI et al}

P-450 by natural steroids: relationship to the induction of $\delta$ aminolevulinate synthase and porphyrin accumulation in the avian embryo. Arch Biochem Biophys 217: 597-608, 1982.

25) Paxton JW, Moore MR, Beattie AD, Goldberg A. 17-Oxosteroid conjugates in plasma and urine of patients with acute intermittent porphyria.
Clin Sci Mol Med 46: 207-222, 1974.

26) Kauppinen R, Mustajoki P. Prognosis of acute porphyria: occurrence of acute attacks, precipitating factors, and associated diseases. Medicine (Baltimore) 71: 1-13, 1992. 